\title{
Article \\ Production and Properties of the Porous Layer Obtained by the Electrochemical Method on the Surface of Austenitic Steel
}

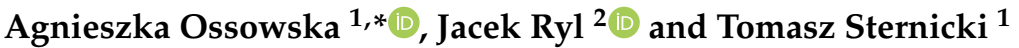 \\ 1 Faculty of Mechanical Engineering and Ship Technology, Gdansk University of Technology, \\ 80-233 Gdańsk, Poland; sternicki.tomasz@gmail.com \\ 2 Advanced Materials Center, Faculty of Applied Physics and Mathematics, Gdansk University of Technology, \\ 80-233 Gdańsk, Poland; jacek.ryl@pg.edu.pl \\ * Correspondence: agnieszka.ossowska@pg.edu.pl
}

Citation: Ossowska, A.; Ryl, J.;

Sternicki, T. Production and

Properties of the Porous Layer

Obtained by the Electrochemical

Method on the Surface of Austenitic

Steel. Materials 2022, 15, 949.

https://doi.org/10.3390/

ma15030949

Academic Editor: Thomas Niendorf

Received: 30 November 2021

Accepted: 19 January 2022

Published: 26 January 2022

Publisher's Note: MDPI stays neutral with regard to jurisdictional claims in published maps and institutional affiliations.

Copyright: (C) 2022 by the authors. Licensee MDPI, Basel, Switzerland. This article is an open access article distributed under the terms and conditions of the Creative Commons Attribution (CC BY) license (https:// creativecommons.org/licenses/by/ $4.0 /)$.

\begin{abstract}
The growing demand for implants has seen increasing interest in the introduction of new technologies and surface modification methods of metal biomaterials. This research aimed to produce and characterize a porous layer grown on austenitic stainless steel 316L, obtained via the anodization process near the micro-arc oxidation, i.e., low voltage micro-arc oxidation (LVMAO). The discussed layer significantly influences the properties of metallic biomedical materials. The surface topography, layer thickness, surface roughness, pore diameter, elemental composition, crystal structure, and surface wettability were assessed for all anodized layers, together with the resultant corrosion resistance. Attention was paid to the influence of the process parameters that affect the specification of the produced layer. The obtained results showed surface development and different sized pores in the modified layers, as well as an increase in corrosion resistance in the Ringer's solution.
\end{abstract}

Keywords: anodization; oxide layer; austenitic stainless steel; porous layer; biomaterial; corrosion resistance

\section{Introduction}

There is currently a growing demand for materials that can replace damaged or weakened bones, joints, muscles, and ligaments. Implanted biomaterials must fulfill several criteria. They must be biocompatible, have long-term endurance to constant and variable stresses, and finally, have corrosion resistance in a physiological environment. A properly selected biomaterial ensures the implant's long-term stability, functionality, and appropriate biological reactions of living tissues in its vicinity. The properties of the biomaterial mainly determine the durability and functionality of the implant, while they are responsible for the biological reactions on its surface: chemical state, surface topography, roughness, wettability, flexibility, surface energy, etc. [1].

Metal biomaterials, including cobalt-chromium alloys $(\mathrm{CoCr})$, titanium (commercially pure Ti) as well as titanium alloys (e.g., Ti-6Al-4V, Ti13Nb13Zr), and stainless steels (316L), have been used for a long time. Due to their high corrosion resistance, good strength, ductility, and high hardness [2], austenitic steels are successfully used as screws, intramedullary nails, fixation elements, etc. They are characterized by a fine-grained structure and a low level of non-metallic inclusions, ensuring adequate strength and ductility of the steel, and reducing the likelihood of cracks. The chemical composition of austenitic steels determines their single-phase and paramagnetic structure, as well as good resistance to pitting corrosion and good mechanical properties [3].

Apart from the appropriate strength properties, the most important criterion for the use of some stainless steels as biomaterials is their biotolerance, which depends on bioelectric, biochemical, and biomechanical factors initiating bacteriological, metabolic, immunological, and oncological processes. Modern alloys used in implantology should meet the criteria of:

- tissue compatibility (biocompatibility), 
- non-toxicity and non-allergic,

- cytotoxic and carcinogenic,

- bioactivity enabling acceleration of the adhesion process with living tissue,

- blood-compatibility,

- no tendency to form clots, which depend on location in the blood stream,

- the contact time of the implant surface with blood,

- the blood flow velocity,

- the chemical composition of the surface [4].

Despite the many advantages of these materials, there are still problems with implant loosening, which may be caused by stress shielding [5-7], the action of pitting or crevice corrosion, and possible allergic reactions. In order to avoid such problems and increase biocompatibility, the bioactivities of austenitic steels are subjected to various types of surface modification processes. The basic methods causing changes in surface quality include mechanical processing (grinding, polishing), laser ablation [8-10], thermal oxidation [11], chemical oxidation [12-14], micro-arc oxidation (MAO) [15], and oxidation with hydrogen peroxide [16] or electrochemical treatment [17-23]. By modifying the electrolyte composition and current values in the electrochemical oxidation, we can obtain layers of different chemical compositions with different structures, e.g., amorphous, nanotube, and as a result of the application of high voltage treatment, porous layers [24,25]. Another advantage of using electrochemical oxidation is the possibility of doping the layers with various ions, e.g., $\mathrm{Au}, \mathrm{Zn}$, or $\mathrm{Cu}[26-29]$.

Different roughness may be obtained when using this type of processing [30,31]. As a result of such surface modification, the abrasive coat [32,33], surface wettability [34-44], adhesion, and biocompatibility [45-48] are changed. Moreover, the oxide layer may influence the osteoinduction processes by changing the oxides' architectural features and chemical composition [49].

The great advantage of porous layers produced by micro-arc oxidation is the enhanced corrosion resistance [50-53], which is an important aspect in the selection of components used for medicine and other industries. Unfortunately, there is little literature on porous layers' characteristics on stainless steel produced by the micro-arc oxidation.

This research is focused on producing and characterizing anodized porous layers with the goal to enhance the properties of metallic biomedical materials. The application of electrochemical oxidation with high values of electric voltage, close to the value of microarc oxidation (LVMAO), made it possible to obtain porous layers with specific pore sizes. Modification of the surface of austenitic 316L steel also improved the corrosion resistance properties.

\section{Materials and Method}

The study was performed on austenitic steel of the grade 316L, with its chemical composition listed in Table 1. The sheet was delivered annealed at $1050^{\circ} \mathrm{C}$.

Table 1. Chemical composition of the 316L alloy, wt. pct. (according to the manufacturer's certificate, Bibus Metals Ltd., Dabrowa, Poland).

\begin{tabular}{cccccccc}
\hline $\mathbf{C}$ & $\mathbf{C r}$ & $\mathbf{N i}$ & $\mathbf{M o}$ & $\mathbf{M n}$ & $\mathbf{S i}$ & $\mathbf{N}$ & $\mathbf{F e}$ \\
\hline 0.03 & 17.64 & 11.97 & 2.15 & 1.71 & 0.71 & 0.053 & bal. \\
\hline
\end{tabular}

The specimens of dimensions $15 \times 10 \mathrm{~mm}$ were cut from the alloy sheet with an initial thickness of $0.7 \mathrm{~mm}$. The samples were ground with abrasive papers (No. 2000 as the last, Struers Inc., Cleveland, OH, USA). Afterward, the specimens were cleaned in an ultrasonic chamber (Sonic-2, Polsonic Palczynski Sp. J., Warszawa, Poland) with isopropanol, methanol (Avantor Performance Materials Poland S.A., Gliwice, Poland), and distilled water, subsequently, for $5 \mathrm{~min}$ in each batch, and finally dried in cold air. 
The LVMAO was made in ethylene glycol $\left(\mathrm{C}_{2} \mathrm{H}_{6} \mathrm{O}_{2}\right.$, pure p.a. $99 \%$, Chempur, Piekary Śląskie, Poland) and perchloric acid $\left(\mathrm{HClO}_{4}, 60 \%\right.$, Chempur, Poland). The tests were performed in a standard electrical circuit composed of an electrochemical cell, power supply, Pt electrode as the polarizing electrode, and the tested metallic electrode. Neither stirring, aeration, nor deaeration were applied. All measurements were performed at room temperature. A charging time of 15 min was used with a constant cell voltage of $100 \mathrm{~V}$, $150 \mathrm{~V}$, or $200 \mathrm{~V}$ (Table 2).

Table 2. The labels of electrochemical oxidation layers formed at process conditions.

\begin{tabular}{ccc}
\hline Sample & $\begin{array}{c}\text { Voltage } \\
{[\text { [V] }}\end{array}$ & $\begin{array}{c}\text { Time } \\
{[\text { Min] }}\end{array}$ \\
\hline I & 100 & 15 \\
II & 150 & 15 \\
III & 200 & 15 \\
\hline
\end{tabular}

The specimens' surfaces and cross-sections after each applied oxidation condition were examined with the scanning electron microscope (SEM JEOL JSM-7600F, JEOL Ltd., Tokyo, Japan), equipped with an LED detector at $5 \mathrm{kV}$ acceleration voltage. The layers' chemical composition was determined using X-ray energy-dispersive spectroscopy (EDS) (Edax Inc., Mahwah, NJ, USA).

The X-ray diffraction studies were carried out using an X-ray diffractometer (Philips X'Pert Pro-MPD, Brighton, UK) system vertical T-T goniometer (190 mm radius). The X-ray source was a long-fine-focus, ceramic $\mathrm{X}$-ray tube with $\mathrm{Cu}$ anode. The standard operating power was $40 \mathrm{kV}, 50 \mathrm{~mA}(2.0 \mathrm{~kW})$. The system optics consisted of programmable divergence, anti-scatter and receiving slits, incident and diffracted beam soller slits, curved graphite diffracted beam monochromator, and a proportional counter detector (Bragg-Brentano parafocusing geometry $\left(2 \Theta\right.$ ca. $\left.5-100^{\circ}\right)$.

The X-ray photoelectron spectroscopy (XPS) measurements were carried out using Escalab 250Xi spectroscope (ThermoFisher Scientific, Waltham, MA, USA), operating with a monochromatic AlK $\alpha$ X-ray source, with a spot size of $250 \mu \mathrm{m}$. The pass energy was $150 \mathrm{eV}$ for survey spectra and $20 \mathrm{eV}$ for high-resolution spectra recorded in $\mathrm{Ni} 2 p, \mathrm{Fe} 2 p, \mathrm{Cr}$ $2 p, M o 3 d$, and $O 1$ s core-level binding energy ranges. Low-energy electron and low-energy $\mathrm{Ar}^{+}$ion flow were used for charge compensation purposes during the experiment, with the final peak calibration using adventitious $C 1$ s peak at $284.6 \mathrm{eV}$. Spectral deconvolution was performed with Avantage software (v.5.973, ThermoFisher Scientific, Waltham, MA, USA).

The nanoindentation tests were performed with the NanoTest Vantage (Micro Materials, Wrexham, UK) equipment using a Berkovich three-sided pyramidal diamond. The maximum applied force was equal to $5 \mathrm{mN}$, the loading and unloading times were set at $20 \mathrm{~s}$, the dwell period at full load was $10 \mathrm{~s}$. The distances between the subsequent indents were $50 \mu \mathrm{m}$. During the indent, the load-displacement curves were determined using the Oliver and Pharr method. Based on the load-penetration curves, the surface hardness $(\mathrm{H})$ and reduced Young's modulus (E) were calculated using the integrated software. The critical process parameters included the maximum force, holding time, and test rate. In calculating Young's modulus (E), a Poisson's ratio of 0.3 was assumed for the titanium oxide layer. The measurements were processed in randomly selected five points for each surface, and the results were averaged.

The water contact angle (wettability) measurements were taken for the reference stainless steel 316L and oxidized specimens using a contact angle goniometer (Zeiss, Jena, Germany) at room temperature. All the analyses were repeated three times.

The electrochemical impedance spectroscopy (EIS) measurements were carried out in a three-electrode setup, with the studied sample as the working electrode, silver chloride electrode as the reference, and Pt mesh as the counter electrode. The studies were performed using Gamry Reference 600+ potentiostat/galvanostat (Gamry Instruments, Warminster, PA, USA). The applied perturbation signal frequency range was set between $40 \mathrm{kHz}$ and 
$10 \mathrm{mHz}$, with a perturbation amplitude of $10 \mathrm{mV}$. This experiment was carried out at $37^{\circ} \mathrm{C}$, the conditioning period before the experiment lasted for $2 \mathrm{~h}$. Naturally aerated Ringer's solution was the studied electrolyte and its volume in the corrosion cell was $100 \mathrm{~mL}$.

\section{Results and Discussion}

\subsection{Microstructure, Surface Topography, Phase, and Chemical Compositions}

Figure 1 presents the morphology of the anodized oxide layers, showing a different structure depending on the process parameters. The layers obtained with the use of the lowest voltage, sample I (100 V), did not uniformly cover the alloy surface (Figure 1b), with visible areas showing an absence of the porous layers. This sample showed only the residuals of the porous layer formation. The gradual increase in the applied voltage made the porous layer cover the samples entirely, as supported by SEM micrographs of samples II and III (Figure 1c,d, respectively). The layers differed not only in the surface morphology, as significant differences were also found in the pore size (Figure 2). For sample I, the produced pores contained the largest proportion of pores with large diameters, from 390 to $469.4 \mathrm{~nm}$. As previously noted, the porous layer did not evenly cover the entire surface of the sample I. There were places on the surface of the samples where the process of formation of the porous layer did not begin. The pore sizes of sample II showed smaller diameters (max. $432 \mathrm{~nm}$ ), and pores with a diameter of 344-402 nm constituted about 75\% of the sample surface. However, for sample III, the maximum diameters of the pores were $426.2 \mathrm{~nm}$. Pores with a diameter of 272-387 nm dominated. The surfaces of sample III showed high homogeneity of the porous layer and a similar size of evenly distributed pores.

Due to the increasing values of the voltage, one should expect divergent thicknesses of the obtained layers (Figure 3 and Table 3), which for layers formed at the surface of samples ranged from $2.1 \mu \mathrm{m}$ (Figure 3a) to $17.5 \mu \mathrm{m}$ (for sample III, Figure 3c), gradually increasing with the increase of the applied anodization voltage.

Table 3. Thickness of the layers after LVMAO with difference potencial.

\begin{tabular}{ccc}
\hline Sample & Thickness $[\mu \mathrm{m}]$ \\
\hline I & $2.3-2.8$ \\
II & $6.0-7.9$ \\
III & $14.3-15.8$ \\
\hline
\end{tabular}

The main factor affecting the formation of the LVMAO layer is the electric field, which overcomes the energy barrier associated with the activation of diffusion of ions from the metallic phase to the oxide phase. Ions migrate through the oxide layer towards the oxide-electrolyte interphase. The low electrical conductivity and high value of the layer's energy barrier require the use of an electric field of $10^{-6}-10^{-8} \mathrm{~V} \mathrm{~cm}{ }^{-1}$, which enables the transport of ions during electrochemical oxidation. A suitable distribution of potentials takes place at the phase boundaries: oxide/electrolyte, metal/oxide. As a result of electrochemical oxidation, the oxide layer thickness for titanium alloys is a function of anodizing potential and time. The applied voltage affects the obtained thickness of the oxide layer [54], while the used electrolyte determines the growth rate, which is the result of the oxide layer formation rate and the oxidation product dissolution rate [55]. The thickness of the layer is an important element preventing direct contact of the material with the external environment. This is a type of barrier that may increase corrosion resistance and thus extend the service life of the element protected by a porous layer applied as a result of the LVMAO process. 
a)
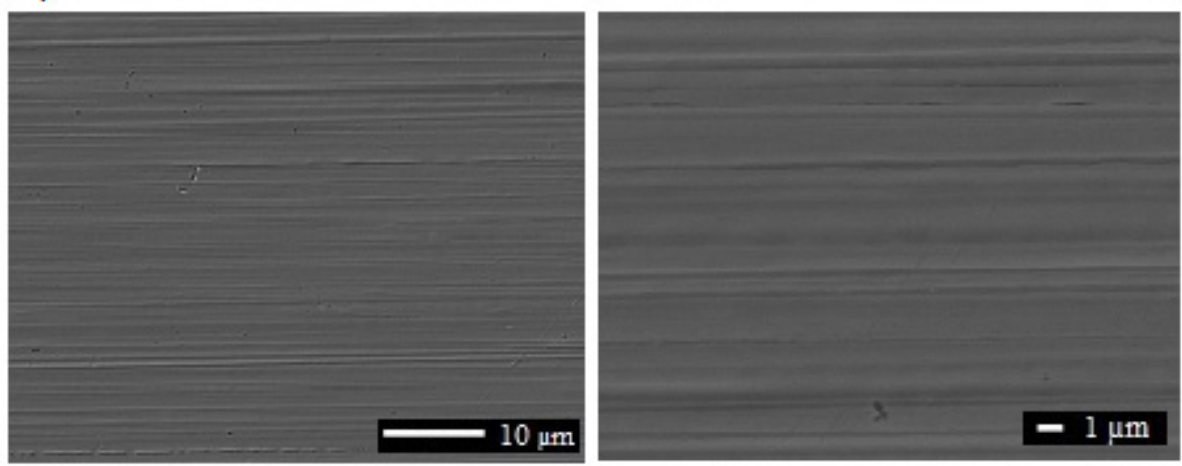

b)
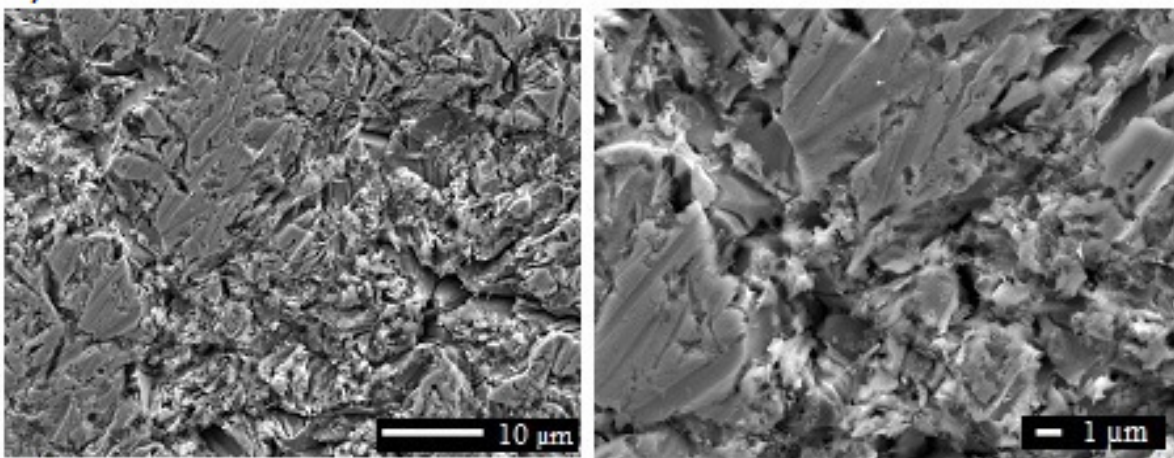

c)
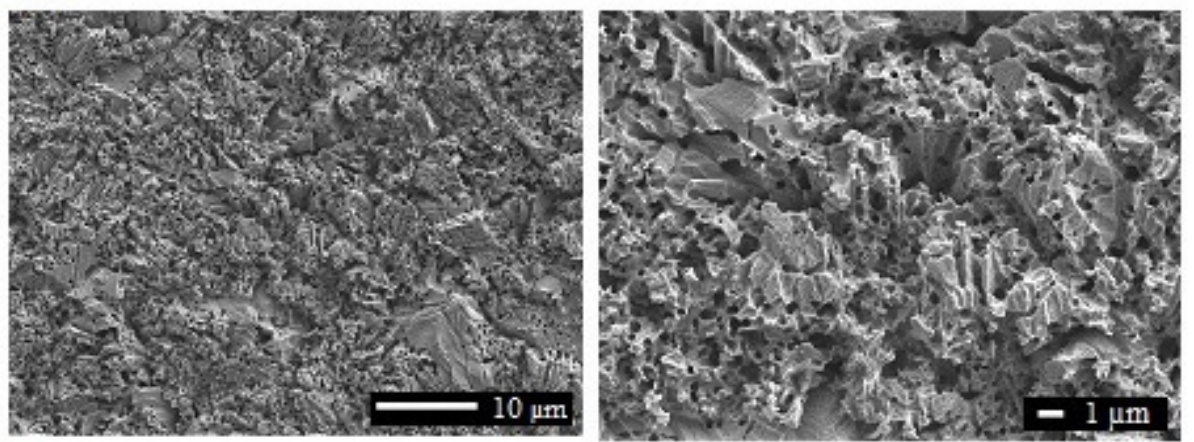

d)
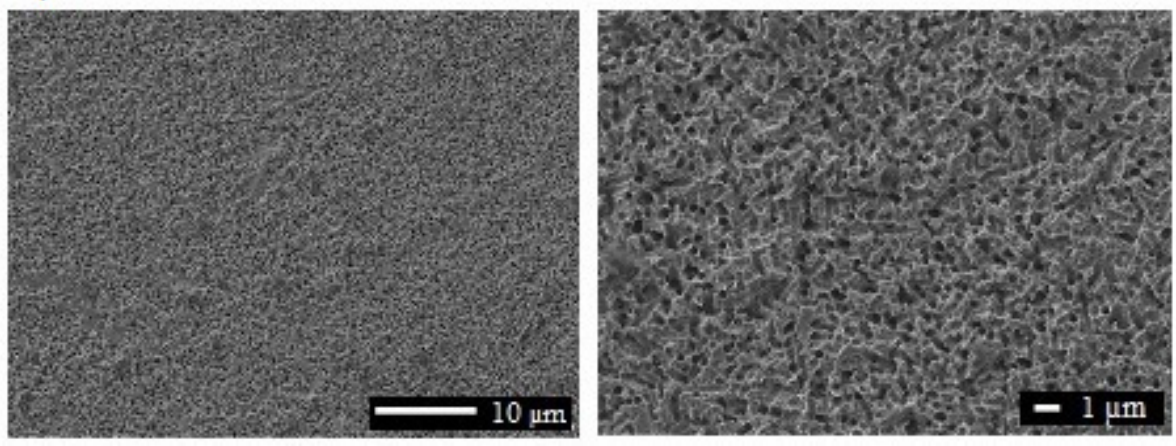

Figure 1. SEM micrographs presenting the morphology of the (a) 316L steel and LVMAO various potencials: (b) sample I with $100 \mathrm{~V}$, (c) sample II with $150 \mathrm{~V}$, (d) sample III with $200 \mathrm{~V}$. 
(a)

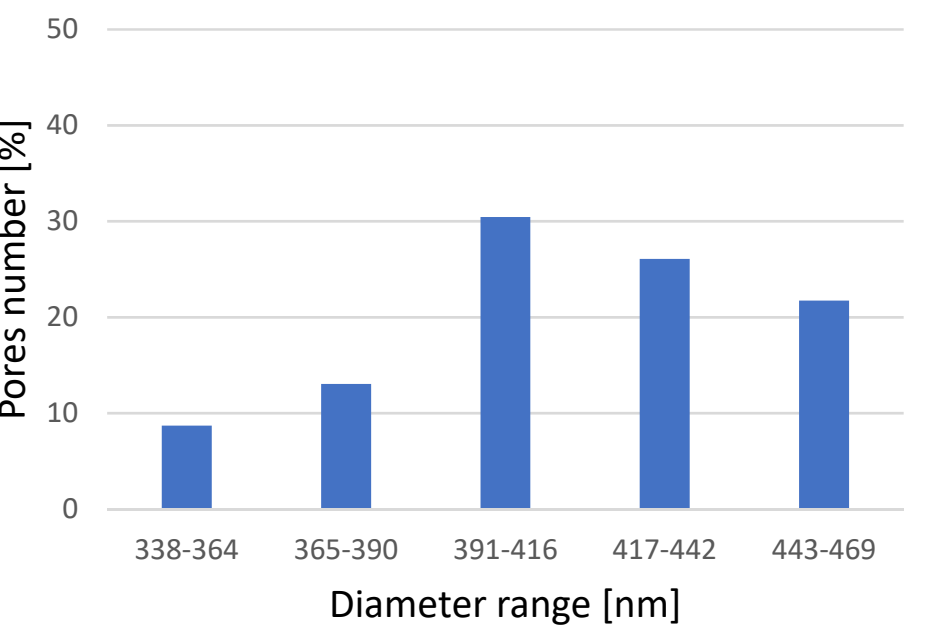

(b)

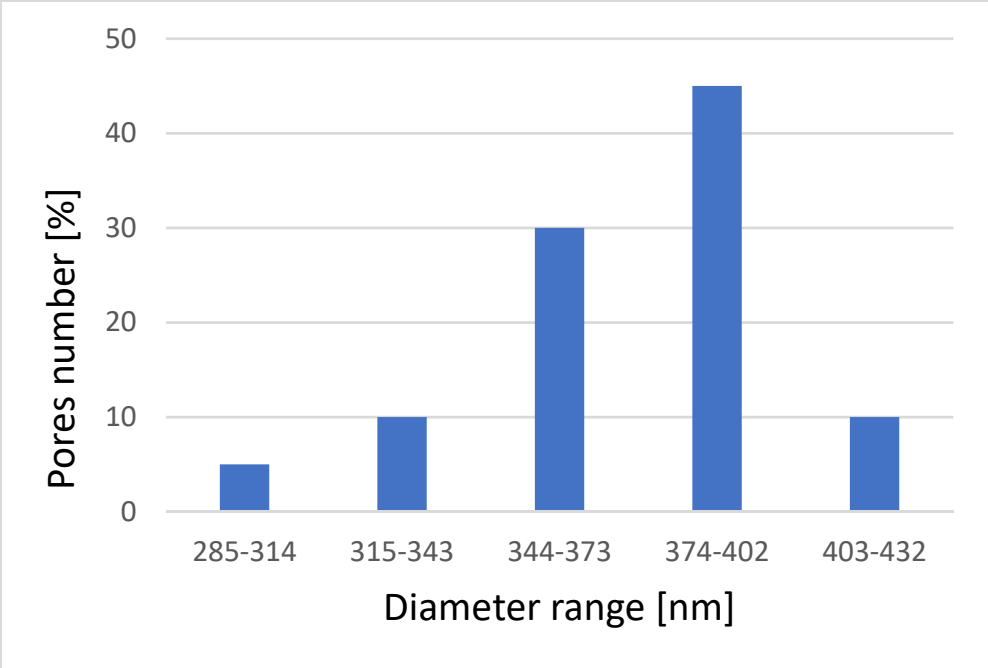

(c)

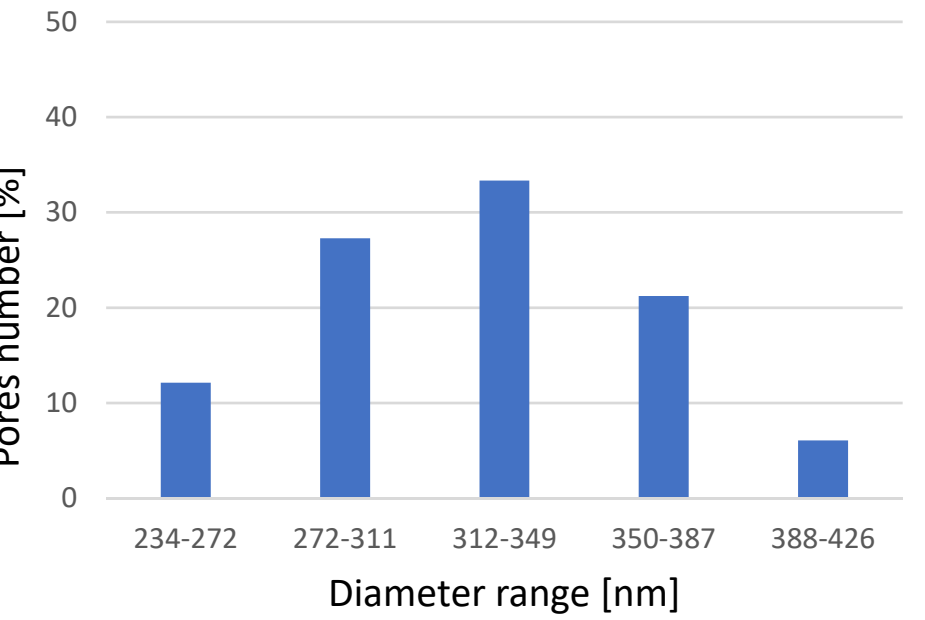

Figure 2. Pore diameters histograms for samples: (a) sample I, (b) sample II, (c) sample III. 
a)

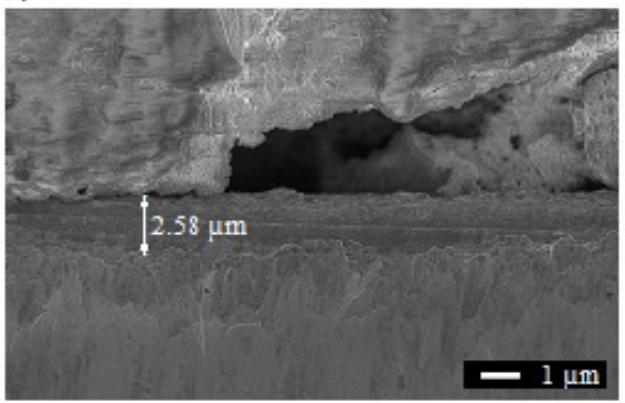

b)

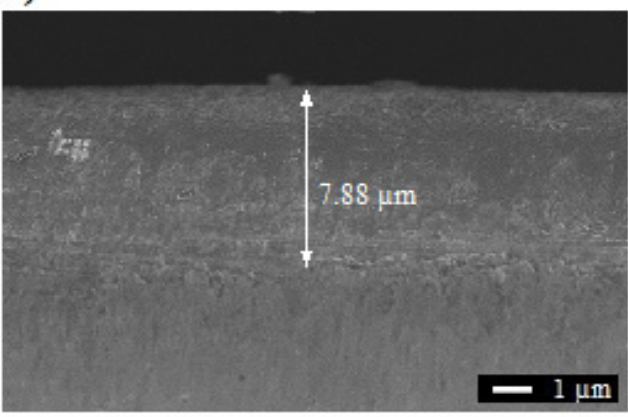

c)

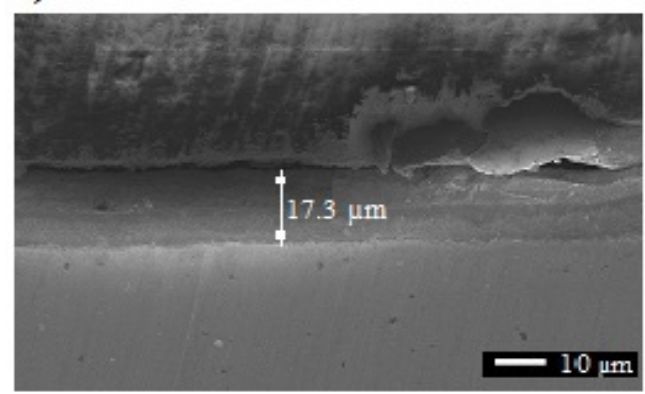

Figure 3. Thickness of the layers: (a) sample I, (b) sample II, (c) sample III.

The results of tests of the chemical composition of the cross-sections of the layers carried out with the use of EDS measurements are presented in Table 4 and Figure 4. In all the produced layers, a decrease in the content of the primary $316 \mathrm{~L}$ alloy components $(\mathrm{Fe}$, $\mathrm{Cr}, \mathrm{Ni}, \mathrm{Mo}$ and $\mathrm{Mn}$ ) and increase in the oxygen content were observed. Analyses of the chemical composition of the layers showed that the content of the primary Fe element in the 316L stainless steel drastically decreased with the increase of the layer thickness and the applied tension. A similar relationship was also observed for Mo. However, with the increase in layer thickness and tension, much higher values of $\mathrm{Cr}$ and $\mathrm{Ni}$ were noted. The increase in the concentration of the elements $\mathrm{Cr}$ and $\mathrm{Ni}$ can be explained by the higher affinity of $\mathrm{Cr}$ and $\mathrm{Ni}$ with oxygen compared to the affinity for $\mathrm{Fe}$, for the formation of chromium oxides and nickel oxides.

Table 4. EDS examinations of tested specimens on the samples cross-sections (in wt.\%).

\begin{tabular}{ccccc}
\hline Element & Reference & Sample I & Sample II & Sample III \\
\hline $\mathrm{Fe}$ & 68.88 & 68.58 & 63.75 & 58.89 \\
$\mathrm{Cr}$ & 16.24 & 14.49 & 15.13 & 15.71 \\
$\mathrm{Ni}$ & 10.72 & 8.96 & 9.62 & 10.38 \\
$\mathrm{Mo}$ & 2.13 & 2.11 & 2.09 & 2.01 \\
$\mathrm{Mn}$ & 1.47 & 1.46 & 1.47 & 1.45 \\
$\mathrm{Si}$ & 0.56 & 0.54 & 0.57 & 0.58 \\
$\mathrm{O}^{*}$ & - & 1.86 & 7.37 & 10.98 \\
\hline
\end{tabular}

$\left.{ }^{*}\right)$ the quantities must be regarded as only informative. 

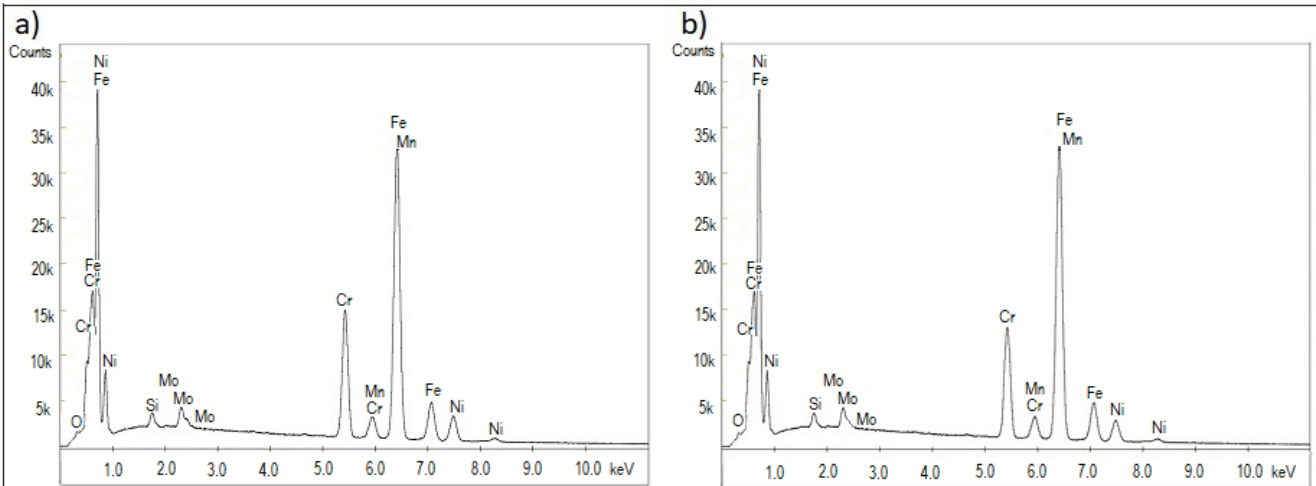

c)

d)
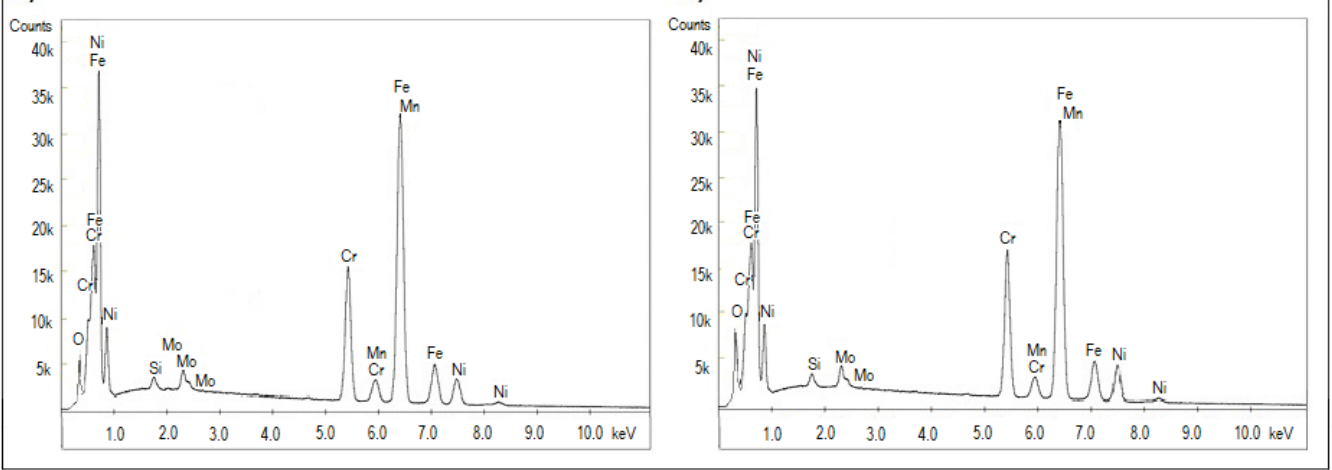

Figure 4. EDS examination of chemical composition of: (a) reference, (b) sample I, (c) sample II, (d) sample III.

Similar results were previously obtained for steel 304 [55], which showed that the composition of the porous layers is similar to the composition substrate (parent material). The research [56] revealed that the concentration of $\mathrm{H}_{2} \mathrm{O}$ in the anodic bath determines the morphological features of these anodically formed layers. Research conducted by Tsuchiya [54] showed that the addition of water to the organic baths also increased the pore diameter. On the other hand, Asoh [50] proved that the influence of the electrolyte and the applied voltage leads to porous layers of different chemical compositions.

The high-resolution XPS analysis, performed for each studied sample, revealed a considerable difference in each LVMAO-formed layer surface chemistry compared to the reference 316L steel sample. This analysis concerns the chemistry of the native passive oxide film on each studied porous layer's surface due to the XPS analysis depth. Figure 5 shows the spectra recorded in the binding energy range of $\mathrm{Cr} 2 p$ (Figure 5a), Fe $2 p$ (Figure 5b), Mo $3 d$ (Figure $5 \mathrm{c}$ ), and Ni $2 p_{3 / 2}$ (Figure $5 \mathrm{~d}$ ).

When considering the reference sample, it may be observed that it is primarily built of iron and chromium compounds. The peak deconvolution of iron Fe $2 p$ spectra (Figure $4 \mathrm{a}$ ) reveals the dominant presence of two peak doublets with $\mathrm{Fe} 2 p_{3 / 2}$ peaks located at 710.3 and $712.3 \mathrm{eV}$, values typically found for the Fe(III) oxidation state, in the form of oxides and hydroxides, respectively [57-59]. However, a small signal from metallic iron with $\mathrm{Fe} 2 p_{3 / 2}$ at $707.0 \mathrm{eV}$ was also found, which attests to the passive film's thickness in the air atmosphere does not exceed approx. $5 \mathrm{~nm}$. The total share of iron among all the metallic atoms identified on the reference sample's surface was 69.2 at.\%, as shown in Table 5. On the other hand, the share of the primary alloying additive, chromium, reaches 26.5 at.\%. This element is primarily found in the form of $\mathrm{Cr}(\mathrm{III})$ oxides $\left(\mathrm{Cr} 2 p_{3 / 2}\right.$ at $\left.576.0 \mathrm{eV}\right)$ and hydroxides $(577.3 \mathrm{eV})$. However, as with iron, a small contribution from metallic $\mathrm{Cr}$ atoms was found [60,61]. Finally, small contributions from $\mathrm{MoO}_{3}$, metallic Mo, and metallic Ni were also recognized, as presented in Table 5 [61-63]. 


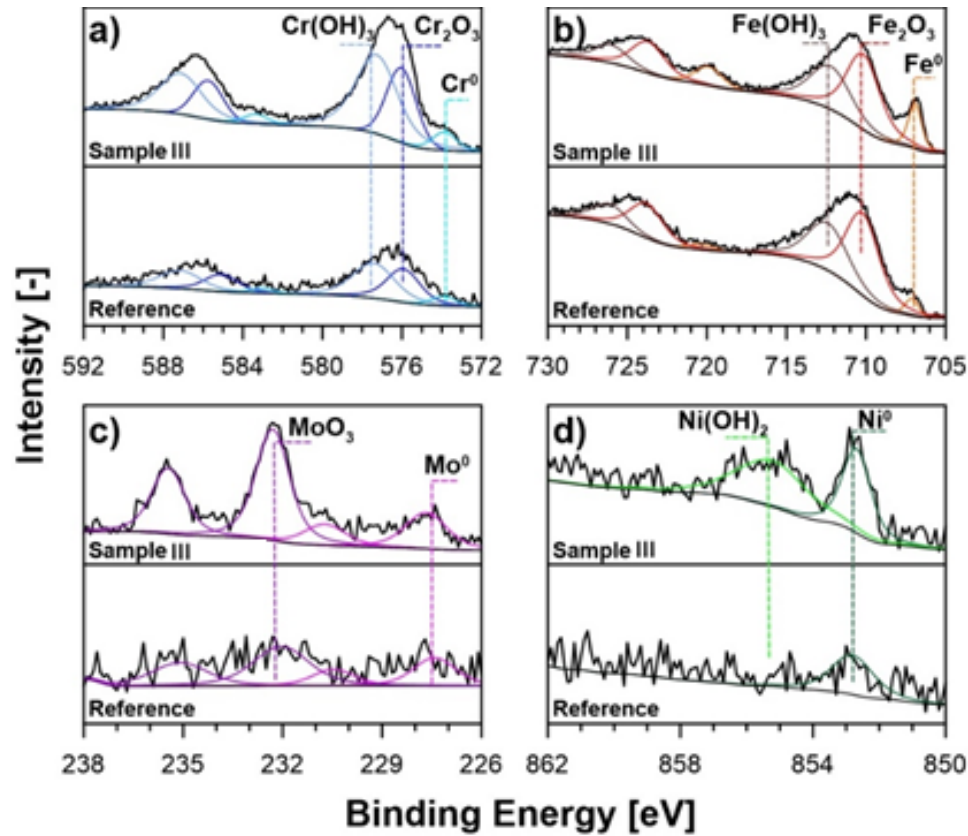

Figure 5. High-resolution XPS spectra for Sample III and reference 316L sample, recorded in the core-level binding energy range of: (a) $\mathrm{Cr} 2 p$, (b) $\mathrm{Fe} 2 p$, (c) $\mathrm{Mo} 3 d$ and (d) $\mathrm{Ni} 2 p_{3 / 2}$.

Table 5. The share of metallic elements and their chemical states, based on the results of highresolution XPS analysis of the studied 316L samples.

\begin{tabular}{|c|c|c|c|c|c|c|c|c|c|c|}
\hline \multirow{2}{*}{$\begin{array}{c}\text { Chemical } \\
\text { State }\end{array}$} & \multicolumn{3}{|c|}{$\mathrm{Fe} 2 p_{3 / 2}$} & \multicolumn{3}{|c|}{$\operatorname{Cr} 2 p_{3 / 2}$} & \multicolumn{2}{|c|}{ Мo $3 d_{7 / 2}$} & \multicolumn{2}{|c|}{$\mathrm{Ni} 2 p_{3 / 2}$} \\
\hline & $\mathrm{Fe}^{0}$ & $\mathrm{Fe}_{2} \mathrm{O}_{3}$ & $\mathrm{Fe}(\mathrm{OH})_{3}$ & $\mathrm{Cr}^{0}$ & $\mathrm{Cr}_{2} \mathrm{O}_{3}$ & $\mathrm{Cr}(\mathrm{OH})_{3}$ & $\mathbf{M o}^{0}$ & $\mathrm{MoO}_{3}$ & $\mathrm{Ni}^{0}$ & $\mathrm{Ni}(\mathrm{OH})_{2}$ \\
\hline $\mathrm{BE}[\mathrm{eV}]$ & 707.0 & 710.3 & 712.3 & 573.9 & 576.0 & 577.3 & 227.7 & 232.3 & 852.8 & 855.4 \\
\hline Reference & 2.9 & 39.2 & 27.1 & 2.2 & 10.5 & 13.8 & 0.8 & 1.4 & 2.1 & 0.0 \\
\hline Sample I & 6.0 & 27.2 & 19.1 & 3.5 & 16.1 & 17.7 & 1.4 & 3.3 & 2.3 & 3.4 \\
\hline Sample II & 5.6 & 29.2 & 17.5 & 2.3 & 14.8 & 19.8 & 1.3 & 3.7 & 2.1 & 3.7 \\
\hline Sample III & 5.9 & 26.1 & 17.8 & 3.1 & 12.9 & 22.6 & 1.9 & 4.6 & 2.2 & 2.9 \\
\hline
\end{tabular}

As a result of the LVMAO porous layer formation, the investigated samples' surface chemistry changes significantly. The XPS analysis revealed that the share of chromium oxides and hydroxides increased by nearly half and up to 35.5 at.\% for Sample III, a layer grown at the polarization voltage of $200 \mathrm{~V}$. A similar observation was made in the case of $\mathrm{MoO}_{3}$ contribution, which amount reaches over 4.6 at.\% among all the studied elements. Notably, the amount of the $\mathrm{Cr}(\mathrm{III})$ and $\mathrm{Mo}(\mathrm{VI})$ oxides/hydroxides depends on and rises with the polarization voltage applied during the anodic layer formation. An opposite conclusion may be drawn when analyzing the chemistry of iron. Here, the total share of iron(III) species drops down from 66.9 to 43.9 at.\% in the case of Sample III. Notably, the electrochemical formation of the porous layer at the surface of 316L steel samples leads to the appearance of the oxidized form of nickel (see Figure $5 \mathrm{~d}$ ), with an $\mathrm{Ni} 2 p_{3 / 2}$ peak at $855.4 \mathrm{eV}$ that was identified as $\mathrm{Ni}(\mathrm{OH})_{2}$ based on the literature survey [62]. Nickel oxides do not typically contribute to the stainless steel passive film [63], while the $\mathrm{Ni}(\mathrm{OH})_{2}$ contribution did not depend on the applied polarization voltage.

The overall conclusion to be drawn is that the formation of the porous layer at the surface of the analyzed stainless steel samples increases the nobility of the elements building the native passive film, which should translate to a higher corrosion resistance of the studied material, most importantly for samples II and III. Another interesting conclusion may be drawn based on the total share of peaks corresponding to the metallic atoms at zero oxidation state $\left(\mathrm{Fe}^{0}, \mathrm{Cr}^{0}, \mathrm{Mo}^{0}\right.$ and $\left.\mathrm{Ni}^{0}\right)$, in that the native passive film at the surface 
of Samples I-III is thinner than this for the reference sample. The effect, however, might originate from the altered surface geometry introduced by the porous layer.

Figure 6 shows the tested samples' diffractograms. Reflections corresponding to the substrate were obtained for sample I and marked as $\mathrm{\gamma}$. On the other hand, for samples II and III, the intensity of the $\gamma$ peaks slightly decreased with the increase of the cut-off voltage, which is probably related to the growth of the porous layer. The measurement results show additional reflections which indicate the share of iron oxides $\left(\mathrm{Fe}_{2} \mathrm{O}_{3}\right.$ and $\left.\mathrm{FeO}\right)$ as a part of the modified surface. The presence of these oxides is visualized in the form of peaks that can be predicted for the 2-theta angles: $44.63^{\circ}-\mathrm{Fe}_{2} \mathrm{O}_{3}$, and $41.81^{\circ}-\mathrm{FeO}$. The reflection corresponding to the $44.63^{\circ} 2$-theta angle is very clear and confirms the XPS findings regarding the significant presence of $\mathrm{Fe}_{2} \mathrm{O}_{3}$ oxide. The intensity of these peaks increased with the increase of the boundary voltage and is probably associated with the strength of the oxidation reaction [64].

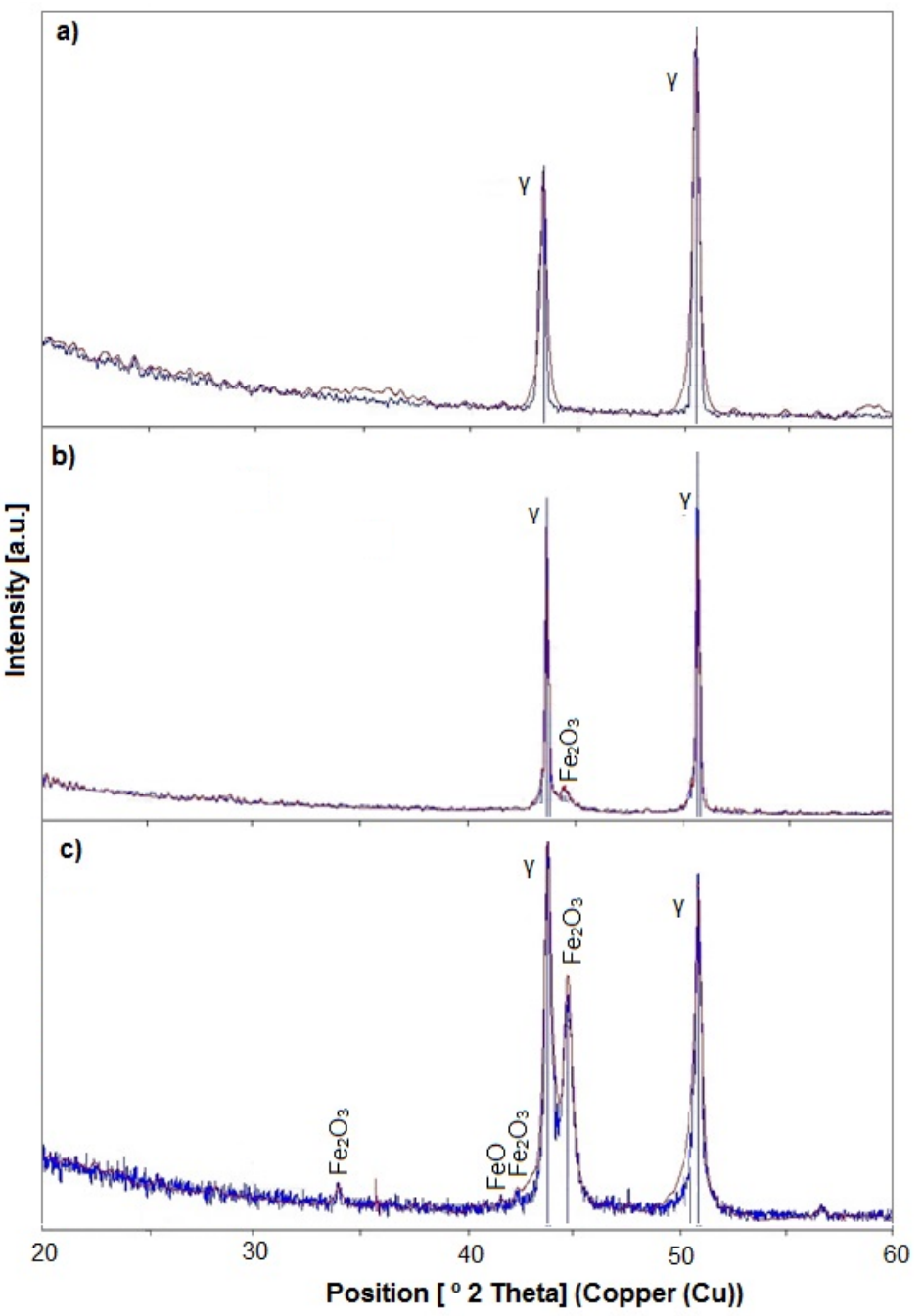

Figure 6. XRD spectrum for: (a) samples I, (b) samples II, (c) samples III.

\subsection{Nanomechanical Properties}

Figure 7 shows the dependence of displacement into the surface on load. The values of nanohardness $(\mathrm{H})$ and Young's modulus $(\mathrm{E})$ of the samples are presented in Table 6. When analyzing the test results, it can be noticed that with the increase of the voltage of the oxidation process, there was an apparent decrease in both $\mathrm{H}$ and $\mathrm{E}$ values for samples with the modified layer. The results of the research may be related to the structure of the formed layers and the size of the pores. The larger the pore diameter, the lower the $\mathrm{H}$ and $\mathrm{E}$ values. The surface quality had a significant influence on the results of the 
nanoindentation measurements. SEM tests for sample I showed areas where pores exist, but also areas on the surface on which the formation of the porous layer has started. Such areas covered a significant part of the sample surface. Perhaps some of the measurements of nanoindentation were made in these places, which would be suggested by the values closest to the results of the nanoindentation measurements carried out on the base material.

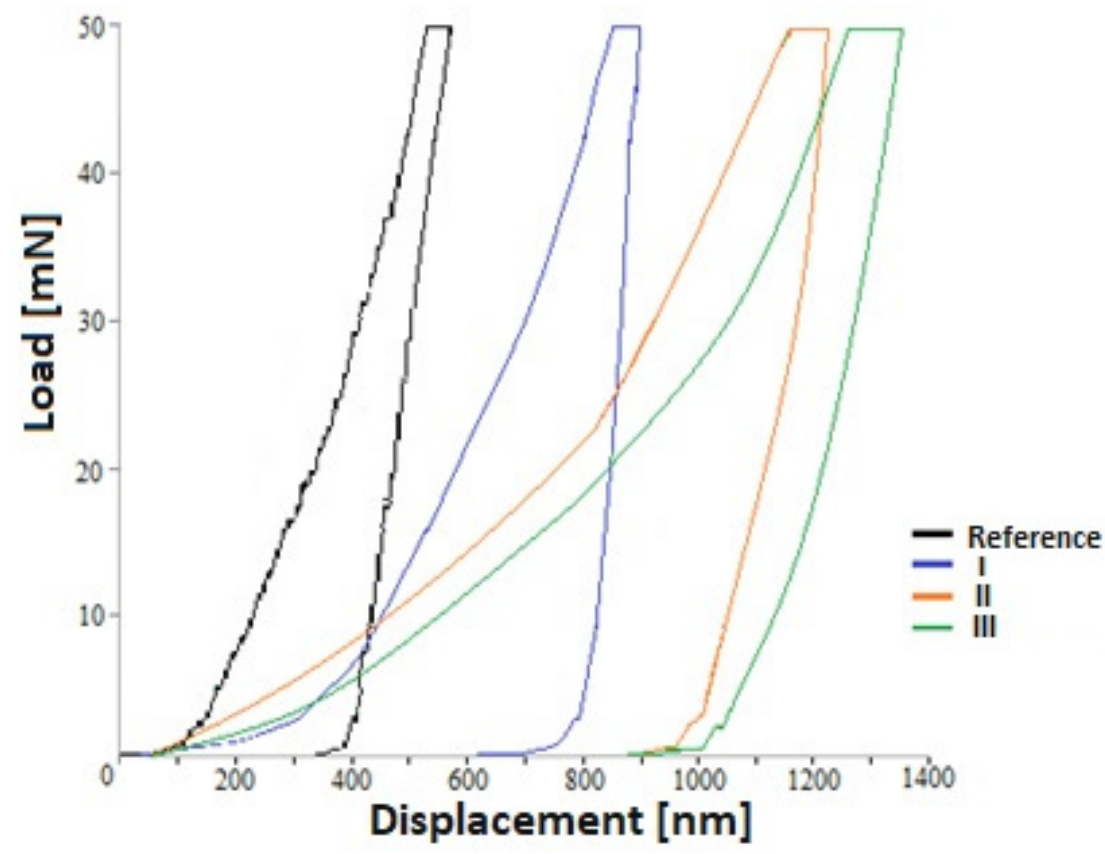

Figure 7. Hysteresis plots of load-deformation for a single indentation measurement.

Table 6. Mechanical properties of the tested specimens.

\begin{tabular}{ccccc}
\hline Sample & $\begin{array}{c}\text { Max. } \\
\text { Depth } \\
\text { (nm) }\end{array}$ & $\begin{array}{c}\text { Plastic } \\
\text { Depth } \\
\mathbf{( n m )}\end{array}$ & $\begin{array}{c}\text { Hardness } \\
\text { (GPa) }\end{array}$ & $\begin{array}{c}\text { Young's } \\
\text { Modulus } \\
\text { (GPa) }\end{array}$ \\
\hline Reference & $214 \pm 15$ & $198 \pm 4$ & $2.89 \pm 0.05$ & $43.48 \pm 0.23$ \\
I & $83 \pm 31$ & $79 \pm 3$ & $2.26 \pm 0.16$ & $16.90 \pm 7.30$ \\
II & $115 \pm 30$ & $107 \pm 7$ & $1.77 \pm 0.21$ & $15.75 \pm 5.09$ \\
III & $131 \pm 22$ & $127 \pm 2$ & $0.92 \pm 0.42$ & $13.10 \pm 4.63$ \\
\hline
\end{tabular}

Surface roughness could induce underestimation of $\mathrm{E}$ and $\mathrm{H}$ at shallow indentation depth (i.e., small load) $[65,66]$. The highest values of the Young's modulus were obtained for 316L and sample I, which at the same time revealed the lowest value of layer thickness, with a heterogeneous structure of the layer and the largest pore diameter.

One of the preliminary bioactivity assessment methods is surface wettability, which is characterized by the contact angle, affecting the degree of adsorption and aggregation of the material. It is related to the physical phenomena occurring on their surface, mainly the surface energy, defined by positively or negatively charged functional groups [64]. It is known [67] that cells do not adhere directly to the surface of the biomaterial, but through a layer of absorbed proteins which become attracted to the surface due to the interaction of electrostatic and van der Waals forces. Cell membrane receptors recognize proteins and activate intracellular receptors, leading to osteoblast adhesion to the implant surface. The adhered cells proliferate and differentiate, leading to the formation of new bone tissue. The degree and time at which the implanted material absorbs moisture from the environment of the human body has a strong influence on protein adsorption and cell adhesion [64] and determines plaque aggregation, water absorption, as well as the hydrophilicity or hydrophobicity of a given material. 
The conducted tests (Table 7) showed that the Ti13Nb13Zr titanium alloy exhibits hydrophobic properties (contact angle value $81^{\circ}$ ), while the titanium oxide layer obtained on the titanium alloy has better hydrophilic properties compared to the pure alloy (contact angle $76^{\circ}$ ). On the other hand, the increase in the LVMAO anodizing voltage caused the contact angle to drop down to $56^{\circ}$ (for sample III). It is known that the best value of the contact angle for attaching cells to the implant was determined to be $55^{\circ}[68,69]$, while the most desirable value of the contact angle for hard tissue regeneration is $35-80^{\circ}[22,68,70]$. Such a low contact angle enabled the efficient adhesion of cells, proteins, and microorganisms on the surface of the implantable material. Its presence can be attributed to the porous structure of the surface. It is known that a low value of the contact angle results in good bioactivity, which enables the adhesion of cells and microorganisms on the surface of the implanted material. Such values of the contact angle accelerate the process of adhesion of the adhesive serum protein to cells, namely fibronectin and vitronectin [69], and such values of the contact angle were obtained. Excessively hydrophobic surfaces enhance cell affinity and reduce biocompatibility, but highly hydrophilic surfaces prevent cell-cell interactions, which are particularly important in tissue engineering $[70,71]$.

Table 7. The contact angle for the water droplet for the tested specimens.

\begin{tabular}{cc}
\hline Sample & Average Contact Angle [ ${ }^{\circ}{ }^{]}$ \\
\hline Reference & $81.93 \pm 2.60$ \\
I & $76.74 \pm 3.43$ \\
II & $63.41 \pm 5.57$ \\
III & $56.40 \pm 3.32$ \\
\hline
\end{tabular}

Finally, the electrochemical impedance spectroscopy (EIS) measurements were performed in order to determine the corrosion resistance of the stainless steels samples obtained by different surface modification protocols. It is one of the most often used techniques to evaluate the corrosion resistance of materials [72,73] in particular for passive films and coatings, where polarization curves analysis may be burdened by high errors. The measurements were carried out in Ringer's solution, at $37^{\circ} \mathrm{C}$ degrees, to imitate the human body fluids environment. The results of the corrosion resistance test are presented in Figure 8 and Table 8 .

Table 8. Electrochemical impedance spectroscopy (EIS) results of the studied porous layers, estimated using selected EEC.

\begin{tabular}{cccccc}
\hline & $\boldsymbol{R}_{\boldsymbol{S}}\left[\mathbf{\Omega} \mathbf{c m}^{\mathbf{2}}\right]$ & $\boldsymbol{Q}\left[\boldsymbol{\mu} \mathbf{F s}^{\mathbf{n}-\mathbf{1}} \mathbf{c m}^{-\mathbf{2}}\right]$ & $\boldsymbol{\alpha}[-]$ & $\boldsymbol{R}_{\boldsymbol{P}}\left[\mathbf{M} \Omega \mathbf{c m}^{\mathbf{2}}\right]$ & Prot.eff [\%] \\
\hline Reference & 327 & 24.8 & 0.76 & 0.5 & - \\
Sample I & 341 & 33.2 & 0.83 & 23.2 & 97.9 \\
Sample II & 345 & 23.3 & 0.88 & 52.5 & 99.1 \\
Sample III & 352 & 20.8 & 0.90 & 34.4 & 98.6 \\
\hline
\end{tabular}

The shape of the impedance spectra shows very high resistance recorded for each studied stainless-steel sample, with the polarization resistance range in hundreds of $\mathrm{k} \Omega$. These are well observed in the Nyquist plot (Figure 6a) and the low-frequency range of the Bode impedance modulus plot (Figure 6b, inset). The impedimetric analysis confirms the XPS observation regarding the higher nobility of samples with formed protective porous layers, leading to the significantly increased corrosion resistance of these samples. 

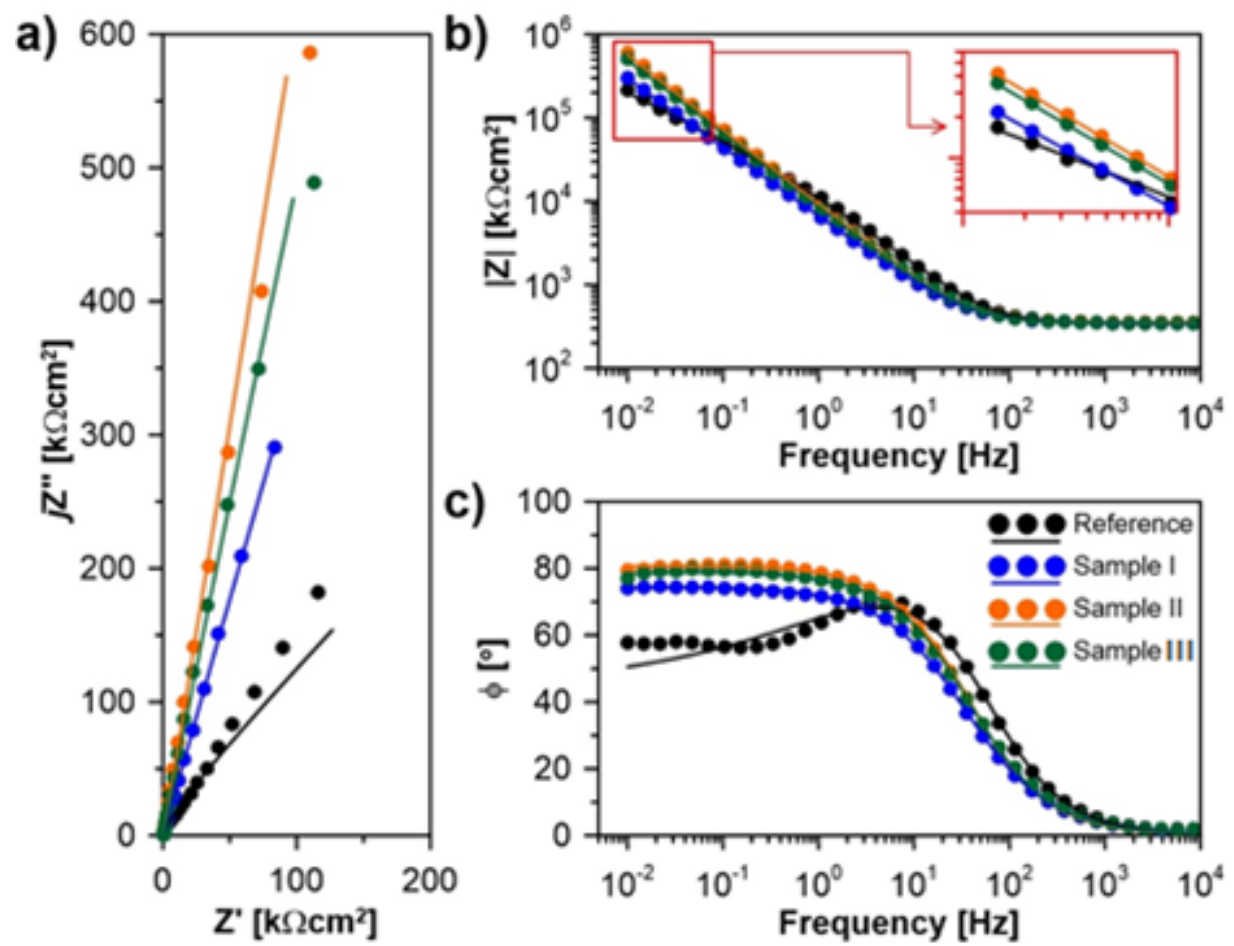

Figure 8. The EIS spectra recorded at open circuit potential conditions for each studied sample exposed to Ringer solution at $37^{\circ} \mathrm{C}$, after $2 \mathrm{~h}$ conditioning, presented in the form of: (a) Nyquist plot, $(\mathbf{b}, \mathbf{c})$ Bode plots of impedance modulus and phase angle, respectively. Experimental results are marked with points and EEC fitting results with solid line.

In order to provide a more detailed explanation, an electric equivalent circuit (EEC) should be selected. Here, we used a classic Randles circuit, modified by using the constant phase element (CPE) instead of the capacitor. The EEC is composed of the series resistance $\mathrm{R}_{\mathrm{S}}$ (electrolyte resistance) and a parallel connection of the resistor $R_{P}$ and CPE, responsible for the charge transfer and accumulation processes occurring at the solid/liquid interface and the passive layer. The role of the CPE is to take into consideration the heterogeneity introduced by surface geometry factors, but also intermetallic phases, steel polycrystallinity, and others $[64,65,72]$. The impedance $Z_{C P E}$ may be described using Equation (1).

$$
Z_{C P E}=\frac{1}{Q(j \omega)^{\alpha}}
$$

where $j$ is an imaginary number, $\omega$ is the angular frequency, $Q$ is the quasi-capacitance of the heterogeneous sample, and $\alpha$ is the CPE exponent. Notably, if $\alpha=1$, the CPE describes the ideal capacitor with capacitance $Q$. Thus, $\alpha$ is often called the heterogeneity factor. The EEC fit quality in a wide frequency range is given by the comparison of the experimental electric parameter values (Figure 8, points) versus fitted values (Figure 8, solid line). The EEC fitting results are summarized in Table 8.

Interestingly, regardless of the porosity of the anodized layer, each sample subjected to near-MAO anodic voltage seems to be characterized by higher electric homogeneity. The $\alpha$ parameter rises from 0.76 for the reference sample to 0.88 and 0.90 for Sample II and Sample III, respectively. These two samples are also characterized with the highest value of the parallel resistance $R_{P}$, which is inversely proportional to the corrosion rate of the investigated steel. However, even for Sample I, which showed the lowest corrosion resistance among all studied layers, the $R_{P}$ value increased by a factor of 46 . A terrific corrosion protection efficiency was noted for each studied coating, ranging from $97.9 \%$ for Sample I to $99.1 \%$ and $98.6 \%$ for Samples II and III, respectively. This parameter was 
adapted from corrosion inhibitor efficiency studies [72,74] and can be estimated using Equation (2).

$$
\text { Prot.eff }=\left(1-\frac{R_{P}^{\text {reference }}}{R_{P}^{\text {coating }}}\right)
$$

\section{Conclusions}

The aim of the work was the modification the surface of 316L steel, which would be characterized by a developed surface topography, a given porosity, and a specific chemical composition. It has been shown that with the use of low voltage micro-arc oxidation (LVMAO), it is possible to produce porous layers, the chemical composition of which depends on the chemical composition of the parent material and the electrolyte used.

An increase in the anodization process voltage causes an increase in the thickness of the layer (almost six times) and changes the size of the pores present in the layer as well as the amount of elements introduced from the solution. At the same time, the tests of the layers show that, as a result of the use of a lower current voltage $(100 \mathrm{~V})$ during the oxidation process, thin layers were obtained, the surfaces of which are not uniform, consisting of areas with a porous structure as well as a slightly modified surface, reflecting the initial stage of the formation of a porous layer. The processes taking place could be considered as standard anodization, during which current peaks are visible, which indicates dissolution of the surface and repeated repassivation. After exceeding the critical voltage, a breakdown of the passive layer is noticed.

The increase in tension ( $200 \mathrm{~V}$ ) affects the structure of the created porous layer, such that evenly spaced pores are visible.

The formed oxides and the layers are very tight, which hinders the diffusion of Fe ions, thus protecting them from further oxidation and contributing to an increase in corrosion resistance. The created porous layer is a specific barrier preventing the penetration of environmental factors into the implant core, as well as the diffusion of the alloy elements to penetrate into the tissues surrounding the implant.

Unfortunately, the porous structure of the layer affects the strength properties of the material. It has been observed that the porous structure of the layers slightly reduces the properties of the layer, mainly $\mathrm{H}$ and $\mathrm{E}$, which affect the wear processes of the layers and indicate susceptibility to plastic deformation. The increase in the voltage used during the electrochemical oxidation process reduces the value of Young's modulus, the values of which are close to the value of the Young's modulus of bone, which has a positive effect.

The hydrophilic surfaces of all samples ensure better cell adhesion and protein adsorption, and contribute to faster integration of the implant into the surrounding tissue.

Based on the test results obtained, the best solution is found with layers made on sample III. The proposed surface modification for various medical applications provides the best properties. Introducing an additional modification of the process consisting in the implementation of, among others, nanometals or pharmaceuticals may increase the interest in this type of solution and open up new possibilities in implantology.

Author Contributions: Conceptualization, A.O.; methodology, A.O., J.R.; validation, A.O., J.R.; formal analysis, A.O., T.S.; investigation, A.O., J.R., T.S.; resources, A.O., J.R.; writing-original draft preparation, A.O.; writing-review and editing, A.O. and J.R. All authors have read and agreed to the published version of the manuscript.

Funding: This research received no external funding.

Institutional Review Board Statement: Not applicable.

Informed Consent Statement: Not applicable.

Data Availability Statement: The data supporting reported results concerning those analyzed or generated during the study are available for inspection by the authors of the article. 
Acknowledgments: We are grateful to Grzegorz Gajowiec (GUT) for his examinations of modified surfaces with the SEM and EDS, Aleksandra Mielewczyk-Gryń (GUT) for the research with XRD.

Conflicts of Interest: The authors declare no conflict of interest.

\section{References}

1. Paital, S.R.; Dahotre, N.B. Calcium phosphate coatings for bio-implant applications: Materials, performance, factors, and methodologies. Mater. Sci. Eng. R Rep. 2009, 66, 1-70. [CrossRef]

2. Geijselaers, H.J.M.; Hilkhuijsen, P.; Bor, T.C.; van den Boogaard, A.H. Large strain cyclic behavior of metastable austenic stainless steel. Mater. Sci. Eng. 2015, A631, 166-172. [CrossRef]

3. Shang, Y.-B.; Shi, H.-J.; Wang, Z.-X.; Zhang, G.-D. In-situ SEM study of short fatigue crack propagation behavior in a dissimilar metal welded joint of nuclear power plant. Mater. Des. 2015, 88, 598-609. [CrossRef]

4. Kasemo, B. Biological surface science. Surf. Sci. 2002, 500, 656-677. [CrossRef]

5. Ferretti, J.L.; Cointry, G.R.; Capozza, R.F.; Frost, H.M. Bone mass, bone strength, muscle-bone interactions, osteopenias and osteoporoses. Mech. Ageing Dev. 2003, 124, 269-279. [CrossRef]

6. Pawlikowski, M.; Skalski, K.; Haraburda, M. Process of hip joint prosthesis design including bone remodelling phenomenon. Comput. Struct. 2003, 81, 887-893. [CrossRef]

7. Spoerke, E.D.; Murray, N.G.; Li, H.; Brinson, C.; Dunand, D.C.; Stupp, S.I. A bioactive titanium foam scaffold for bone repair. Acta Biomater. 2005, 1, 523-533. [CrossRef]

8. Bizi-Bandoki, P.; Benayoun, S.; Valette, S.; Beaugiraud, B.; Audouard, E. Modifications of roughness and wettability properties of metals induced by femtosecond laser treatment. Appl. Surf. Sci. 2011, 257, 5213-5218. [CrossRef]

9. Martínez-Calderon, M.; Rodríguez, A.; Dias-Ponte, A.; Morant-Miñana, M.C.; Gómez-Aranzadi, M.; Olaizola, S.M. Femtosecond laser fabrication of highly hydrophobic stainless steel surface with hierarchical structures fabricated by combining ordered microstructures and LIPSS. Appl. Surf. Sci. 2016, 374, 81-89. [CrossRef]

10. Mroczkowska, K.; Gassiorek, J.; Mazur-Nowacka, A.; Szczygieł, B.; Antończak, A.J. Adhesion and corrosion resistance of laser-oxidized titanium in potential biomedical application. Surf. Coat. Technol. 2019, 366, 179-189. [CrossRef]

11. Aniołek, K.; Kupka, M.; Barylski, A. Sliding wear resistance of oxide layers formed on a titanium surface during thermal oxidation. Wear 2016, 356-357, 23-29. [CrossRef]

12. Kim, J.H.; Mirzaei, A.; Kim, H.W.; Kim, S.S. Facile fabrication of superhydrophobic surfaces from austenitic stainless steel (AISI 304) by chemical etching. Appl. Surf. Sci. 2018, 439, 598-604. [CrossRef]

13. Pantoja, M.; Velasco, F.; Abenojar, J.; Martinez, M.A. Development of superhydrophobic coatings on AISI 304 austenitic stainless steel with different surface pretreatments. Thin Solid Film. 2019, 671, 22-30. [CrossRef]

14. Gao, L.; Yang, S.; Yang, H.; Ma, T. One-Stage Method for fabricating superhydrophobic stainless steel surface and its anti-corrosion performance. Adv. Eng. Mater. 2017, 19, 1600511. [CrossRef]

15. Gao, A.; Hang, R.; Bai, L.; Tang, B.; Chu, P.K. Electrochemical surface engineering of titanium-based alloys for biomedical application. Electrochim. Acta 2018, 271, 699-718. [CrossRef]

16. Khodaei, M.; Kelishadi, S.H. The effect of different oxidizing ions on hydrogen peroxide treatment of titanium dental implant. Surf. Coat. Technol. 2018, 353, 158-162. [CrossRef]

17. Choi, W.T.; Oh, K.; Singh, P.M.; Breedveld, V.; Hess, D.W. Wettability control of stainless steel surfaces via evolution of intrinsic grain structures. J. Mater. Sci. 2016, 51, 5196-5206. [CrossRef]

18. Borgioli, F.; Galvanetto, E.; Bacci, T. Effects of surface modification by means of low-temperature plasma nitriding wetting and corrosion behavior of austenitic stainless steel. Coatings 2020, 10, 98. [CrossRef]

19. Choi, W.T.; Oh, K.; Singh, P.M.; Breedveld, V.; Hess, D.W. Hydrophobicity and improved localized corrosion resistance of grain boundary etched stainless steel in chloride-containing environment. J. Electrochem. Soc. 2017, 164, C61-C65. [CrossRef]

20. Habibzadeh, S.; Li, L.; Shum-Tim, D.; Davis, E.C.; Omanovic, S. Electrochemical polishing as a 316L stainless steel surface treatment method: Towards the improvement of biocompatibility. Corros. Sci. 2014, 87, 89-100. [CrossRef]

21. O'Brien, B.; Carroll, W. The evolution of cardiovascular stent materials and surfaces in response to clinical drivers: A review. Acta Biomater. 2009, 5, 945-958. [CrossRef] [PubMed]

22. Ossowska, A.; Zieliński, A.; Olive, J.-M.; Wojtowicz, A.; Szweda, P. Influence of two-stage anodization on properties of the oxide coatings on the Ti-13Nb-13Zr alloy. Coatings 2020, 10, 707-727. [CrossRef]

23. Ossowska, A.; Beutner, R.; Scharnweber, D.; Zieliński, A. Properties of the composite oxide layers on the Ti13Nb13Zr alloy. Surf. Eng. 2017, 33, 841-848. [CrossRef]

24. Pawlik, A.; Hnida, K.; Socha, R.P.; Wiercigroch, E.; Małek, K.; Sulka, G.D. Effects of anodizing conditions and annealing temperature on the morphology and crystalline structure of anodic oxide layers grown on iron. Appl. Surf. Sci. 2017, 426, 1084-1093. [CrossRef]

25. Klimas, V.; Pakštas, V.; Vrublevsky, I.; Chernyakova, K.; Jagminas, A. Fabrication and characterization of anodic films onto the type-304 stainless steel in glycerol electrolyte. J. Phys. Chem. C 2013, 117, 20730-20737. [CrossRef]

26. Lin, D.J.; Fuh, L.J.; Chen, C.Y.; Chen, W.C.; Lin, J.H.C.; Chen, C.C. Rapid nano-scale surface modification on micro-arc oxidation coated titanium by microwave-assisted hydrothermal process. Mater. Sci. Eng. C 2019, 95, 236-247. [CrossRef] 
27. He, X.; Zhang, X.; Wang, X.; Qin, L. Review of antibacterial activity of titanium-based implants' surfaces fabricated by micro-arc oxidation. Coatings 2017, 7, 45. [CrossRef]

28. Lim, S.-G.; Choe, H.-C. Bioactive apatite formation on PEO-treated Ti-6Al-4V alloy after 3rd anodic titanium oxidation. Appl. Surf. Sci. 2019, 484, 365-373. [CrossRef]

29. Cordeiro, J.M.; Nagay, B.E.; Ribeiro, A.L.R.; da Cruz, N.C.; Rangel, E.C.; Fais, L.M.G.; Vaz, L.G.; Barão, V.A.R. Functionalization of an experimental Ti-Nb-Zr-Ta alloy with a biomimetic coating produced by plasma electrolytic oxidation. J. Alloy Compd. 2019, 770, 1038-1048. [CrossRef]

30. Burstein, G.T.; Vines, S.P. Repetitive nucleation of corrosion pits on stainless steel and the efects of surface roughness. J. Electrochem. Soc. 2001, 148, 504-516. [CrossRef]

31. Hilbert, L.R.; Bagge-Ravn, D.; Kold, J.; Gram, L. Influence of surface roughness of stainless steel on microbial adhesion and corrosion resistance. Int. Biodeterior. Biodegrad. 2003, 52, 175-185. [CrossRef]

32. Gachot, C.; Rosenkranz, A.; Hsu, S.M.; Costa, H.L. A critical assessment of surface texturing for friction and wear improvement Wear 2017, 372-373, 21-41. [CrossRef]

33. Grützmacher, P.G.; Profito, F.J.; Rosenkranz, A. Multi-scale surface texturing in tribology—current knowledge and future perspectives. Lubricants 2019, 7, 95. [CrossRef]

34. Quéré, D. Wetting and Roughness. Annu. Rev. Mater. Res. 2008, 38, 71-99. Available online: https://www.semanticscholar.org/ paper/Wetting-and-Roughness-Qu/ecd2f3fb1cc2d5c64a5d35d1cf666022fabf3cb7 (accessed on 1 February 2021). [CrossRef]

35. Cao, L.; Hu, H.A.; Gao, D. Design and fabrication of micro-textures for inducing a superhydrophobic behavior on hydrophilic materials. Langmuir 2007, 23, 4310-4314. [CrossRef]

36. Duan, J.-A.; Dong, X.; Yin, K.; Yang, S.; Chu, D. A hierarchical superaerophilic cone: Robust spontaneous and directional transport of gas bubbles. Appl. Phys. Lett. 2018, 113, 203704. [CrossRef]

37. Sheng, Y.J.; Jiang, S.; Tsao, H.K. Effects of geometrical characteristics of surface roughness on droplet wetting. J. Chem. Phys. 2007, 127, 234704. [CrossRef]

38. Whyman, G.; Bormashenko, E. How to make the Cassie wetting state stable? Langmuir 2011, 27, 8171-8176. [CrossRef]

39. Tuteja, A.; Choi, W.; Mckinley, G.H.; Cohen, R.E.; Rubner, M.F. Design parameters for superhydrophobicity and superoleophobicity. MRS Bull. 2008, 33, 752-758. [CrossRef]

40. Kota, A.K.; Mabry, J.M.; Tuteja, A. Superoleophobic surfaces: Design criteria and recent studies. Surf. Innov. 2013, 1, 71-83. [CrossRef]

41. Liu, K.; Jiang, L. Metallic surfaces with special wettability. Nanoscale 2011, 3, 825-838. [CrossRef] [PubMed]

42. Yin, K.; Du, H.; Dong, X.; Wang, C.; Duan, J.-A.; He, J. A simple way to achieve bioinspired hybrid wettability surface with micro/nanopatterns for e_cient fog collection. Nanoscale 2017, 9, 14620-14626. [CrossRef] [PubMed]

43. Yang, S.; Yin, K.; Chu, D.; He, J.; Duan, J.-A. Femtosecond laser structuring of Janus foam: Water spontaneous antigravity unidirectional penetration and pumping. Appl. Phys. Lett. 2018, 113, 203701. [CrossRef]

44. Yang, S.; Yin, K.; Wu, J.; Wu, Z.; Chu, D.; He, J.; Duan, J.-A. Ultrafast nano-structuring of superwetting Ti foam with robust antifouling and stability towards e_cient oil-in-water emulsion separation. Nanoscale 2019, 11, 17607-17614. [CrossRef]

45. Roach, P.; Eglin, D.; Rohde, K.; Perry, C.C. Modern biomaterials: A review-Bulk properties and implications of surface modifications. J. Mater. Sci. Mater. Med. 2007, 18, 1263-1277. [CrossRef]

46. Von Recum, A.F.; Shannon, C.E.; Cannon, C.E.; Long, K.J.; van Kooten, T.G.; Meyle, J. Surface roughness, porosity, and texture as modifiers of cellular adhesion. Tissue Eng. 2007, 2, 241-253. [CrossRef]

47. Elter, P.; Sickel, F.; Ewald, A. Nanoscaled periodic surface structures of medical stainless steel and their e_ect on osteoblast cells Acta Biomater. 2009, 5, 1468-1473. [CrossRef]

48. Ossowska, A.; Zieliński, A. The mechanisms of degradation of titanium dental implants. Coatings 2020, 10, 836-850. [CrossRef]

49. Pradhan, D.; Wren, A.W.; Misture, S.T.; Mellott, N.P. Investigating the structure and biocompatibility of niobium and titanium oxides as coatings for orthopedic metallic implants. Mater. Sci. Eng. C 2016, 58, 918-926. [CrossRef]

50. Asoh, H.; Nakatani, M.; Ono, S. Fabrication of thick nanoporous oxide films on stainless steel via DC anodization and subsequent biofunctionalization. Surf. Coat. Technol. 2016, 307, 441-451. [CrossRef]

51. Rangaraju, R.R.; Raja, K.S.; Panday, A.; Misra, M. An investigation on room temperature synthesis of vertically oriented arrays of iron oxide nanotubes by anodization of iron. Electrochim. Acta 2010, 55, 785-793. [CrossRef]

52. Zhong, Z.; Qin, J.; Ma, J. Cellulose acetate/hydroxyapatite/chitosan coatings for improved corrosion resistance and bioactivity. Mat. Sci. Eng. C Mater. 2015, 49, 251-255. [CrossRef] [PubMed]

53. Shayan, M.; Moradi, M.; Plakseychuk, A.Y.; Shankar, R.; Chun, Y. Osteoblast cell response to oxide films formed on nanograin 316L stainless steel obtained by two-dimensional linear plane-strain machining. Mater. Lett. 2016, 177, 94-98. [CrossRef]

54. Tsuchiya, H.; Suzumura, T.; Terada, Y.; Fujimoto, S. Formation of self-organized pores on type 316 stainless steel in organic solvents. Electrochim. Acta 2012, 82, 333-338. [CrossRef]

55. Doff, J.; Archibong, P.E.; Jones, G.; Koroleva, E.V.; Skeldon, P.; Thompson, G.E. Formation and composition of nanoporous films on 316L stainless steel by pulsed polarization. Electrochim. Acta 2011, 56, 3225-3237. [CrossRef]

56. Kure, K.; Konno, Y.; Tsuji, E.; Skeldon, P.; Thompson, G.E.; Habazaki, H. Formation of self-organized nanoporous anodic films on type 304 stainless steel. Electrochem. Commun. 2012, 21, 1-4. [CrossRef] 
57. Zhou, T.; Cao, Z.; Zhang, P.; Ma, H.; Gao, Z.; Wang, H.; Lu, Y.; He, J.; Zhao, Y. Transition metal ions regulated oxygen evolution reaction performance of Ni-based hydroxides hierarchical nanoarrays. Sci. Rep. 2017, 7, 46154. [CrossRef]

58. Pai, R.; Singh, A.; Simotwo, S.; Kalra, V. In situ grown iron oxides on carbon nanofibers as freestanding anodes in aqueous supercapacitors. Adv. Eng. Mater. 2018, 20, 1701116. [CrossRef]

59. Amin, M.A.; Saracoglu, M.; El-Bagoury, N.; Sharshar, T.; Ibrahim, M.M.; Wysocka, J.; Krakowiak, S.; Ryl, J. Microstructure and corrosion behaviour of carbon steel and ferritic and austenitic stainless steels in $\mathrm{NaCl}$ solutions and the effect of p-nitrophenyl phosphate disodium salt. Int. J. Electrochem. Sci. 2016, 11, 10029-10052. [CrossRef]

60. Payne, B.P.; Biesinger, M.C.; McIntyre, N.S. X-ray photoelectron spectroscopy studies of reactions on chromium metal and chromium oxide surfaces. J. Electron. Spectros. Relat. Phenom. 2011, 184, 29-37. [CrossRef]

61. Biesinger, M.C.; Payne, B.P.; Grosvenor, A.P.; Lau, L.W.M.; Gerson, A.R.; Smart, R.S.C. Resolving surface chemical states in XPS analysis of first row transition metals, oxides and hydroxides: Cr, Mn, Fe, Co and Ni. Appl. Surf. Sci. 2011, 257, 2717-2730. [CrossRef]

62. Wu, H.; Lian, K. The development of pseudocapacitive molybdenum oxynitride electrodes for supercapacitors. ECS Trans. 2014, 58, 67-75. [CrossRef]

63. Tardio, S.; Abel, M.-L. Comparative study of the native oxide on 361L stainless steel by XPS and ToF-SIMS. J. Vac. Sci. Technol. A 2015, 33, 05E122. [CrossRef]

64. Thomson, S.P.; Loughlan, J. Enhancing the post-bucking response of composite panel structure utilizing shape memory alloy actostors- a smart structural concept. Compos. Struct. 2001, 51, 21-36. [CrossRef]

65. Chen, Z.; Wang, X.; Bhakhri, V.; Giuliani, F.A. Atkinson Nanoindentation of porous bulk and thin films of La ${ }_{0.6}$ Sr0.4Co0.2Fe0.8O3- . Acta Mat. 2013, 61, 5720-5734. [CrossRef]

66. Chen, Z. Nanoindentation of Macro-Porous Materials for Elastic Modulus and Hardness Determination. Applied Nanoindentation in Advanced Materials; Tiwari, A., Natarajan, S., Eds.; John Wiley \& Sons, Ltd.: Hoboken, NJ, USA, 2017; pp. 135-156. [CrossRef]

67. Faucheux, N.; Schweiss, R.; Lutzow, K.; Werner, C.; Groth, T. Self-assembled monolayers with different terminating groups as model substrates for cell adhesion studies. Biomaterials 2004, 25, 2721-2730. [CrossRef]

68. Menzies, K.L.; Jones, L. The Impact of Contact Angle on the Biocompatibility of Biomaterials. Optom. Vis. Sci. 2010, 87, 387-399. [CrossRef]

69. Arima, Y.; Iwata, H. Effect of wettability and surface functional groups on protein adsorption and cell adhesion using well-defined mixed self-assembled monolayers. Biomaterials 2007, 28, 3074-3082. [CrossRef]

70. Zhou, W.; Zhong, X.; Wu, X.; Yuan, L.; Zhao, Z.; Wang, H.; Xia, Y.; Feng, Y.; He, J.; Chen, W. The effect of surface roughness and wettability of nanostructures $\mathrm{TiO}_{2}$ film on TCA- 8113 epithelial-like cells. Surf. Coat. Technol. 2006, 200, 6155-6160. [CrossRef]

71. Wysocka, J.; Cieslik, M.; Krakowiak, S.; Ryl, J. Carboxylic acids as efficient corrosion inhibitors of aluminium alloys in alkaline media. Electrochim. Acta 2018, 289, 175-192. [CrossRef]

72. Jorcin, J.-B.; Orazem, M.E.; Pebere, N.; Tribollet, B. EPC analysis by local electrochemical impedance spectroscopy. Electrochim. Acta 2006, 51, 1473-1479. [CrossRef]

73. Macdonald, D. Some advantages and pitfalls of electrochemical impedance spectroscopy. Corrosion 1990, 46, 229-242. [CrossRef]

74. Ryl, J.; Wysocka, J.; Cieslik, M.; Gerengi, H.; Ossowski, T.; Krakowiak, S.; Niedzialkowski, P. Understanding the origin of high corrosion inhibition efficiency of bee products towards aluminium alloys in alkaline environments. Electrochim. Acta 2019, 304, 263-274. [CrossRef] 